\title{
LISTA RANKINGOWA \\ 10 NAJLEPSZYCH PUBLIKACJI BIBLIJNYCH \\ W POLSCE W R. 1996
}

Podobnie jak w roku ubiegłym Redakcja „Ruchu Biblijnego i Liturgicznego" pozwoliła sobie wytypować 10 najlepszych książek z zakresu biblistyki, wydanych w języku polskim w roku kalendarzowym 1996.

Lista rankingowa obejmuje dwie kategorie:

A. publikacje autorów lub wydawców polskich,

B. tłumaczenia autorów obcych.

Nie oznacza to, że nie było w tymże roku 1996 innych godnych odnotowania pozycji o tematyce biblijnej.

Publikowana lista jest oceną honorową i nie na charakteru komercjalnego.

\section{A. AUTORZY POLSCY}

1. Anna Świderkówna, Rozmów o Biblii ciąg dalszy, Wydawnictwo Naukowe PWN, Warszawa 1996 (łącznie z pozycją tejże, Rozmowy o Biblii, Warszawa 1994).

2. Ks. Lech Stachowiak, Księga Izajasza I (1-39), II-III (40-66), 2 tomy, Pallottinum, Poznań 1996.

3. Psatterz Biblii greckiej, przekład i komentarz ks. Antoni Tronina, Redakcja Wydawnictw KUL, Lublin 1996.

4. Konkordancja wyrazów greckich Nowego Testamentu wraz z Biblia. Nowego Testamentu $w$ systemie Stronga oraz Wykazem wyrazów i zwrotów polskich w NT Biblii Gdańskiej, Wydawnictwo „Na Straży”, Kraków 1996.

5. Piotr Muchowski, Rękopisy znad Morza Martwego. Qumran - Wadi Murabbaa'at - Masada, The Enigma Press, Kraków 1996.

6. Caly świat nie pomieściłby ksiag. Staropolskie opowieści i przekazy apokryficzne, wyd. Wojciech R. Rzepka i Wiesław Wydra, Wydawnictwo Naukowe PWN, Warszawa-Poznań 1996.

7. Do Ziemi Świętej. Najstarsze opisy pielgrzymek do Ziemi Świętej (IVVIII w.), opr. Piotr Iwaszkiewicz, Wydawnictwo WAM, Kraków 1996.

\section{B. TLUMACZENIA}

8. Biblia dla kazdego. Tekst - komentarz - ilustracje, tom I, red. ks. Henryk Witczyk, Wydawnictwo Jedność, Kielce 1996.

9. James C. VanderKam, Manuskrypty znad Morza Martwego, przekł. Regina Gromacka, Wydawnictwo Cyklady, Warszawa 1996.

10. Vittorio Messori, Umęczon pod Ponckim Piłatem? Badania nad męką i śmiercią Jezusa, tłum. ks. Mieczysław Stebart COr, Wydawnictwo „m”- Wydawnictwo OO. Franciszkanów, Kraków-Niepokalanów 1996.

Vivant sequentes A.D. 1997! 